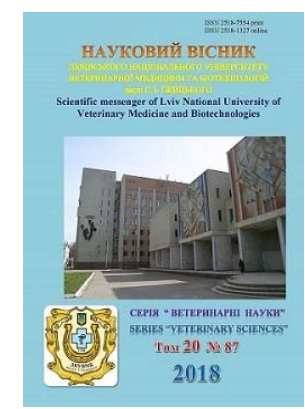

\author{
Науковий вісник Дьвівського національного університету \\ ветеринарної медицини та біотехнологій імені С.З. Гжицького
}

\author{
Scientific Messenger of Lviv National University \\ of Veterinary Medicine and Biotechnologies
}

\title{
Application of intrauterine aerosol preparation for the treatment of cows with postpartum complications
}

\author{
O.A. Katsaraba ${ }^{1}$, V.Y. Stefanyk ${ }^{1}$, Ye.Ye. Kostyshyn ${ }^{1}$, R.N. Sachuk ${ }^{2}$, O.V. Kulinich ${ }^{3}$ \\ ${ }^{1}$ Stepan Gzhytskyi National University of Veterinary Medicine and Biotechnologies Lviv, Ukraine \\ ${ }^{2}$ Research Epizootology Station IVM NAAS, Rivne, Ukraine \\ ${ }^{3}$ Institute of Veterinary Medicine, National Academy of Sciences of Ukraine, Kyiv, Ukraine
}

Article info

Received 05.02.2018

Received in revised form 20.03 .2018

Accepted 26.03.2018

Stepan Gzhytskyi National University of Veterinary Medicine and Biotechnologies Lviv,

Pekarska Str., 50, Lviv, 79010, Ukraine.

Tel.: +38-067-670-68-46

E-mail:Katsaraba@gmail.com

Research Epizootology Station IVM NAAS, Knyaz Vladimir Str., 16/18,

33028, Rivne, Ukraine.

Tel: + 38-097-671-90-63

E-mail: sachuk.08@ukr.net

Institute of Veterinary Medicine, National Academy of Sciences of Ukraine, Donetsk Str., 30, Kyiv, 03151, Ukraine.
Katsaraba, O.A., Stefanyk, V.Y., Kostyshyn, Ye.Ye., Sachuk, R.N., \& Kulinich, O.V. (2018). Application of intrauterine aerosol preparation for the treatment of cows with postpartum compli-cations. Scientific Messenger of Lviv National University of Veterinary Medicine and Biotechnologies. 20(87), 55-59. doi: 10.15421/nvlvet8711

Despite the detailed study of the causes of postpartum endometritis in cows, its course and the implementation of therapeutic and prophylactic measures aimed at preventing obstetric and gynecological pathology, this problem remains extremely relevant and requires comprehensive improvement. Traditional treatment regimens for cows using local therapy include not always effective intrauterine drugs. Therefore, for the treatment of postnatal infections in animals it is better to use highly active drugs in the form of complexes with aerosols. The purpose of the work was to study the therapeutic and prophylactic properties of the foam-forming aerosol preparation "Yodozol» with the comprehensive use of the drugs "Uterodev» and "Devivit Complex» at postpartum endometritis in cows. To study the therapeutic efficacy of the drug «Yodozol» in combination with these drugs, an experimental group (intravenously 1 bottle of foaming aerosol preparation "Yodozol», twice with an interval of 5 days, "Uterodev» was injected intramuscularly in a dose of $10 \mathrm{ml}$ twice with an interval of 24 hours, «Devivit Complex» was administered once intramuscularly at a dose of $30 \mathrm{ml}$ of a single animal product, «BTF plus» subcutaneously at a dose of $15 \mathrm{ml}$ per animal at an interval of 24 hours for 5 days) and control (intramuscularly administered «Yodopen» suppositories 1 suppository 1 time per day with an interval of 24 hours for 3 days, together with subcutaneous single dose "Oxytocin» in a dose of $6 \mathrm{ml}$ per animal) per 10 animals in each of which the postnatal endometritis was diagnosed. Before and after the administration of drugs in cows suffering from postpartum endometritis, blood was taken for general blood analysis, which was taken aseptically from the jugular vein until the morning feeding. The number of erythrocytes and leukocytes was determined by direct counting in the counting chamber of Goryaev's net, hemoglobin - by Sali method. In the blood of cows after administration of drugs, the content of erythrocytes increased by 1.3 times $(P \leq 0.05)$, leukocytes and hemoglobin increased by 1.1 times $(P \leq 0.05)$, compared with similar indices prior to administration, indicating stimulation of erythrocytes and leukopoiesis. The use of «Yodozol» aerosol in combination with "Uterodev», "Devivit Complex» and «BTF plus» preparations during 7 days provided $90 \%$ recovery of cows. In the control group of cows, recovery was observed in $65 \%$ of cows for 10 days. After recovery of experimental group cows, the service period decreased by $53.0 \pm 6.0$ days $(P \leq 0.05)$, the index of insemination decreased by 0.6 units, as compared to similar indicators of control cows.

Key words: cows, obstetric pathology, postpartum endometritis, "Yodozol», "Uterodev», "Devivit Complex», «BTF plus».

\section{Застосування внутрішньоматкового аерозольного препарату для терапії корів при післяродових ускладненнях}

\author{
О.А. Кацараба ${ }^{1}$, В.Ю. Стефаник ${ }^{1}$, С.Є. Костишин ${ }^{1}$, Р.М. Сачук ${ }^{2}$, О.В. Кулініч ${ }^{3}$ \\ ${ }^{1}$ Львівський національний університет ветеринарної медицини та біотехнологій імені. С.3. Гжииького, \\ м. Львів, Украӥна
}


${ }^{2}$ Дослідна станиія епізоотологї ІВМ НААН, Рівне, Україна

Інститут ветеринарної медииини НААН, Київ, Україна

Незважаючи на детальне вивчення причин виникнення післяродового ендометриту корів, його перебігу і проведення лікувальнопрофілактичних заходів, спрямованих на запобігання акушерської та гінекологічної патології, дана проблема залишається надзвичайно актуальною та потребує всебічного удосконалення. Традичійні схеми лікування корів із застосуванням місиевої терапії включають не завжди ефективні внутрішньоматкові препарати. Тому для лікування післяродових інфекиій у тварин краще застосовувати високоактивні препарати у формі комплексів із аерозолями. Метою роботи було вивчення лікувально-профілактичних властивостей піноутворюючого аерозольного препарату «Йодозол» із комплексним використанням препаратів «Утеродев», «Девівіт Комплекс» та «БТФ плюс» при післяродовому ендометриті у корів. Для вивчення терапевтичної ефективності препарату «Йодозол» в комплексі із зазначеними препаратами було сформовано дослідну групу (внутрішньоматково 1 балон піноутворюючого аерозольного препарату «Йодозол», дворазово із інтервалом 5 діб, «Утеродев» внутрішньом'язово у дозі 10 мл дворазово з інтервалом 24 години, «Девівіт Комплекс» одноразово внутрішньом'язово у дозі 30 мл препарату одній тварині, «БТФ плюс» підикірно у дозі 15 мл на одну тварину з інтервалом 24 години протягом 5 діб) і контрольну (інтраутерально вводили супозиторіі «Йодопен» по 1 супозиторії 1 раз на добу з інтервалом 24 години протягом 3 діб, разом із підикірним одноразовим введенням «Окситоцин» у дозі 6 мл на тварину) по 10 тварин у кожній, в яких діагностували післяродовий ендометрит. До та після введення препаратів у корів, хворих на післяродовий ендометрит, відбирали кров для проведення загального аналізу крові. Кількість еритрочитів та лейкочитів визначали шляхом прямого підрахунку в лічильній камері сітки Горяєва, гемоглобін - методом Салі. У крові корів після застосування препаратів вміст еритроиитів підвищувався в 1,3 рази $(P \leq 0,05)$, лейкоцитів і гемоглобіну - в 1,1 рази $(P$ $\leq 0,05)$, порівняно із аналогічними показниками до його введення, що вказує на стимулювання еритро- та лейкопоезу. Застосування аерозолю «Йодозол» в комплексі із препаратами «Утеродевом», «Девівіт Комплексом» та «БТФ плюсом» протягом 7 діб забезпечувало видужання 90\% корів. У контрольній групі корів спостерігали видужання у 65\% корів протягом 10 діб. Після видужсання корів дослідної групи, сервіс-період у них скоротився на 53,0 \pm 6,0 доби (P $\leq 0,05)$, індекс осіменіння зменшився на 0,6 одиниці, порівняно з аналогічними показниками корів контрольної групи.

Ключові слова: корови, акушерська патологія, післяродовий ендометрит, «Йодозол», «Утеродев», «Девівіт Комплекс», «БТФ плюс».

\section{Вступ}

Запальні процеси у статевих органах самок великої рогатої худоби часто спричиняють розлади відтворної здатності, які проявляються тривалими перегулами, зниженням запліднюваності, неплідністю, що призводить до зменшення продуктивності та вибраковування тварин. Найбільш поширеним захворюванням корів у післяотельний період є гострий післяродовий ендометрит (Sidashova and Gumenny, 2017; Kobylyukh et al., 2017). Своєчасне виявлення та ефективне лікування цієї патології $є$ запорукою стабільного відтворення стада.

Погіршення умов навколишнього середовища, незадовільна якість кормів (нестача в раціоні вітамінів, мінеральних речовин, білка, вуглеводів, згодовування неякісних кормів, які містять афлатоксини, нітрати, солі важких металів, підвищена кількість масляної кислоти та ін.), патологічні роди, затримання посліду, субінволюція матки, порушення обміну речовин, непрофесійна акушерська допомога, незадовільні санітарно-гігієнічні умови утримання (відсутність або обмеження моціону, недостатнє ультрафіолетове опромінення, порушення зоогігієнічних параметрів мікроклімату та санітарних норм у приміщеннях, надмірна дія стресів) і неправильна експлуатація тварин (тривала лактація, вкорочений або подовжений сухостійний період, порушення режимів машинного доїння, технології одержання сперми, невиконання ветеринарно-санітарних правил у відтворенні, передчасне використання для відтворення молодих тварин), зниження ефективності лікувально-профілактичної роботи спричиняє захворювання репродуктивних органів у корів (Williams et al., 2005; Barlund et al., 2008; Stefanyk et al., 2009).

Враховуючи поліетіологічний характер виникнення ендометритів, профілактика і лікування цієї пато- логії повинні бути комплексними, спрямованими на пригнічення патогенної мікрофлори, підвищення тонусу і стимуляції функції скорочення матки, видалення з її порожнини патологічного ексудату, прискорення відновлення слизової оболонки матки, поліпшення імунобіологічної реактивності, відновлення гормонального балансу та відтворної функції організму корів (Stravskyy et al., 2015; Katsaraba et al., 2017).

За несвоєчасної діагностики та неефективного лікування тварин із запальними процесами в матці захворювання може набувати хронічного характеру, розвивається тривала або постійна неплідність із зниженням молочної продуктивності або припиненням лактації.

Проведення грунтовних досліджень у цьому напрямі $\epsilon$ необхідною умовою раннього прогнозування, діагностики та профілактики гострого післяродового ендометриту у корів.

Незважаючи на детальне вивчення причин виникнення і перебіг післяродового ендометриту та лікувально-профілактичні заходи, спрямовані на запобігання акушерсько-гінекологічних патологій, дана проблема залишається надзвичайно актуальною та потребує всебічного удосконалення (Ivashkiv et al., 2012; Savc et al., 2016).

Тому лікування ендометриту повинно проводитись за принципом комплексного і послідовного застосування необхідних засобів етіотропної, симптоматичної, патогенетичної та замінної дії, враховувати ступінь та характер ураження, супутні захворювання, індивідуальну реактивність та чутливість хворого організму (Heidarpour et al., 2012; Hopper, 2015).

Мета $і$ завдання роботи - вивчити лікувальнопрофілактичні властивості піноутворюючого аерозолю «Йодозол» у комплексні 3 використанням препаратів «Утеродев», «Девівіт Комплекс» та «БТФ плюс» при післяродовому ендометриті у корів. 


\section{Матеріал і методи досліджень}

Дослідження проводили на коровах української чорно-рябої молочної породи віком 4-6 років, живою масою 490-500 кг, продуктивністю 5000-6000 кг молока за лактацію, що належали ФГ «Мрія» Рівненського району Рівненської області.

Для вивчення терапевтичної ефективності «Йодозолу» було сформовано дослідну і контрольну групи по 10 тварин, у яких діагностували післяродовий ендометрит.

Тваринам дослідної групи вводили піноутворюючий аерозольний препарат «Йодозол» дворазово із інтервалом 5 діб (1 балон 45,0 г містить діючі речовини: йод - 0,2 г, наповнювач - пропеллент - 53 мл), у комплексі з використанням «Утеродев», «Девівіт Комплекс» та «БТФ плюс». Препарат «Утеродев» вводили внутрішньом'язово у дозі 10 мл на тварину дворазово 3 інтервалом 24 години. «Девівіт Комплекс» застосовували одноразово внутрішньом'язово у такій дозі - 30 мл препарату одній тварині. «БТФ плюс» підшкірно у дозі 15 мл на одну тварину з інтервалом 24 години протягом 5 діб.

Коровам контрольної групи інтраутерально вводили супозиторії «Йодопен» по 1 супозиторії 1 раз на добу з інтервалом 24 години протягом 3 діб, разом із підшкірним одноразовим введенням препарату «Окситоцин» у дозі 6 мл на тварину.

У корів, хворих на гострий післяродовий ендометрит, до та після введення препаратів, асептично 3 яремної вени до вранішньої годівлі, відбирали кров для проведення загального аналізу. Кількість еритроцитів та лейкоцитів визначали шляхом прямого підрахунку в лічильній камері сітки Горяєва, гемоглобін - методом Салі.

При клінічному обстеженні піддослідних корів користувалися загальноприйнятими методами: оцінювали загальний стан тварин, характер виділень з матки, вимірювали температуру тіла тварин. При ректальному дослідженні звертали увагу на форму та розмір матки, симетричність рогів, консистенцію та їх здатність до скорочення.

Терапевтичну та профілактичну дію препарату встановлювали за тривалістю сервіс-періоду та індексом осіменіння.

Статистичну обробку одержаних цифрових даних проводили за допомогою комп'ютерних програм. Різницю між двома величинами вважали вірогідною за * $-\mathrm{P} \leq 0,05 ; * *-\mathrm{P} \leq 0,01 ; * * *-\mathrm{P} \leq 0,001$.

Фармакологічна дія препарату «Йодозол» обумовлюється з тривалим виділенням молекулярного йоду, що має сильний окислювальний ефект, впливає на обмін речовин, посилює дисиміляцію. Присутність органічних речовин зменшує його бактерицидну дію. Піноутворююча основа забезпечує вплив активної речовини на всю внутрішню поверхню стінки матки та їі роги.

Застосовують препарат для профілактики та лікування післяродових внутрішньоматкових інфекцій у корів, свиней, овець і кіз (ендометриту, піометри, цервіциту, вагініту, затримки посліду), після надання рододопомоги, кесаревого розтину та післяродової санації матки.

«Утеродев» містить діючу речовину: пропаранолол гідрохлорид - відноситься до групи речовин-бетаадреноблокаторів, дія яких полягає у блокуванні адренорецепторів, чутливих до ряду гормонів та медіаторів (адреналін, норадреналін), що проявляється підвищенням скоротливості міометрію та антистресовими властивостями.

Препарат можна призначати великій та дрібній рогатій худобі, свиням для стимуляції родової діяльності, атонії та гіпотонії матки, профілактики післяродових ускладнень (затримка посліду, синдром ММА тощо), для комплексного лікування ендометритів та метритів, поліпшення заплідненості, отримання ембріонів у тварин-донорів.

«Девівіт Комплекс» - комплексний полівітамінний препарат, який застосовується для корекції та нормалізації обмінних процесів у тварин. Вітаміни, які входять до складу препарату, беруть участь у біохімічних процесах в організмі тварин (у формі ензимовітамінів, гормоновітамінів. антиоксидантів). Комплексний вплив діючих речовин препарату призводить до підвищення інтенсивності росту і розвитку тварин, резистентності та продуктивності через стимуляцію протікання обмінних процесів.

«БТФ плюс» - комплексний препарат, який застосовується для корекції та нормалізації обмінних процесів у тварин та птиці. Бутафосфан - похідне фосфорної кислоти. Володіє тонізуючою дією, є адаптогеном та стимулятором обмінних процесів, підвищує резистентність організму до комплексу негативних факторів, сприяє росту та розвитку тварин. Наявність додаткового компоненту L-карнітину забезпечує активацію та регуляцію окисно-відновних процесів в організмі та обміну речовин, володіє анаболічною дією.

\section{Результати та їх обговорення}

При клінічному дослідженні хворих тварин 3 післяродовим ендометритом спостерігали погіршення загального стану організму, зниження апетиту, підвищення температури тіла в межах від 40 до $41^{\circ} \mathrm{C}$, прискорення частоти дихання до 53 рухів за хвилину i пульсу до 104 ударів за хвилину. Із зовнішніх статевих органів виділявся рідкий мутний ексудат сірого кольору, нерідко $з$ домішками крові та іхорозним запахом. При ректальному дослідженні встановлювали збільшення об'єму матки, потовщення й дряблість рогів, іноді флюктуацію й болючість.

Важливим критерієм оцінки фізіологічного стану тварини були морфологічні показники крові корів до та після застосування препаратів, які наведені в таблиці 1.

У крові корів після застосування препарату «Йодозол» вміст еритроцитів підвищувався в 1,3 раза $(\mathrm{P} \leq 0,05)$, лейкоцитів i гемоглобіну - в 1,1 раза $(\mathrm{P} \leq 0,05)$, порівняно із аналогічними показниками до його введення, що вказує на стимулювання еритро- та лейкопоезу. 


\section{Таблиця1}

Морфологічні показники крові корів до та після застосування препарату «Йодозол», $\mathrm{M} \pm \mathrm{m}, \mathrm{n}=10$

\begin{tabular}{lcc}
\hline \multirow{2}{*}{ Показники } & \multicolumn{2}{c}{ Дослідна група корів } \\
\cline { 2 - 3 } & до введення препарату & після введення препарату \\
\hline Еритроцити, Т/л & $5,26 \pm 0,15$ & $6,81 \pm 0,07^{*}$ \\
Лейкоцити, Г/л & $8,25 \pm 0,15$ & $9,10 \pm 0,13^{*}$ \\
Гемоглобін, г/л & $97,17 \pm 0,99$ & $104,6 \pm 0,3^{*}$ \\
\hline
\end{tabular}

Примітка: * - $\mathrm{P} \leq 0,05$ порівняно із показниками крові корів до застосування препарату

Комплексна терапія, в основі якої було внутрішньоматкове введення піноутворюючого аерозольного препарату «Йодозол», забезпечувало покращення клінічного стану корів дослідної групи уже через чотири доби після початку введення препарату. У корів контрольної групи, яким вводили супозиторії «Йодопен» та препарат «Окситоцин», покращення клінічного стану організму спостерігали лише на шосту добу. У тварин підвищилась активність, покращився апетит та поступово відновлювалась продуктивність. При ректальному дослідженні розміри матки зменшились, роги матки лише трохи звисали у черевну порожнину, діаметр рогів був в межах 3-4 см, матка ригідна. На четверту добу 3 початку введення препаратів виділення 3 матки стали прозорими та в'язкими, їхня кількість зменшувалася порівняно 3 контрольними тваринами.

Отже, застосування аерозолю «Йодозол» в комплексі $з$ препаратами «Утеродевом», «Девівіт Комплексом» та «БТФ плюс» забезпечувало видужання 90\% корів впродовж 7 діб. У контрольній групі корів спостерігали видужання у 65\% корів протягом 10 діб (табл. 2).

Таблиця 2

Ефективність лікування корів, хворих на ендометрит

\begin{tabular}{lccc}
\hline Групи корів & $\begin{array}{c}\text { Захворіло, } \\
\text { корів }\end{array}$ & $\begin{array}{c}\text { Видужало, } \\
\text { корів }\end{array}$ & $\begin{array}{c}\text { Термін оду- } \\
\text { жання, діб }\end{array}$ \\
\hline Дослідна & 10 & 9 & 7 \\
Контрольна & 10 & 6 & 10 \\
\hline
\end{tabular}

Про результативність лікувальної дії препаратів ми робили висновок за тривалістю сервіс-періоду та індексом осіменіння корів. Отримані в результаті досліду дані наведено в таблиці 3.

\section{Таблиця 3}

Вплив препарату «Йодозол» на показники відтворної функції корів, $\mathrm{M} \pm \mathrm{m}, \mathrm{n}=10$

\begin{tabular}{lcc}
\hline Групи корів & Сервіс-період, діб & Індекс осіменіння \\
\hline Дослідна & $55,0 \pm 6,0^{*}$ & 1,2 \\
Контрольна & $108,0 \pm 6,0$ & 1,8 \\
\hline Примітка: ${ }^{*}-\mathrm{P} \leq 0,05$ порівняно з коровами контрольної групи
\end{tabular}

Встановлено, що у корів дослідної групи сервісперіод скоротився на 53,0 $\pm 6,0$ доби (P $\leq 0,05)$, індекс осіменіння зменшився на 0,6 одиниці, порівняно 3 аналогічними показниками корів контрольної групи.

Підсумовуючи результати дослідження, запропоновано схему лікування корів 3 післяродовим ендометритом, що включає дворазове із інтервалом 5 діб внутрішньоматкове введення аерозолю «Йодозол» (у дозі 1 балон піноутворюючого аерозольного препарату) в комплексі з застосуванням ін'єкцій препаратів «Утеродевом» (у дозі 10 мл дворазово з інтервалом 24 години) «Девівіт Комплексу» (одноразово у дозі 30 мл препарату одній тварині) та «БТФ плюс» (у дозі 15 мл на одну тварину з інтервалом 24 години протягом 5 діб).

\section{Висновки}

Застосування аерозолю «Йодозол» в комплексі із препаратами «Утеродев», «Девівіт Комплекс» та «БТФ плюс» протягом 7 діб забезпечувало видужання 90\% корів. У контрольній групі корів спостерігали видужання у 65\% корів протягом 10 діб. Після видужання корів дослідної групи сервіс-період скоротився на 53,0 $\pm 6,0$ доби $(\mathrm{P} \leq 0,05)$, індекс осіменіння зменшився на 0,6 одиниці, порівняно з аналогічними показниками корів контрольної групи.

Перспективи подальших досліджень. Планується з'ясувати вплив препарату місцевої дії «Йодозол» в комплексі з «Утеродевом», «Девівіт Комплексом» та «БТФ плюс» при лікуванні інших видів свійських тварин, а також при інших видах акушерської та гінекологічної патології.

\section{References}

Barlund, C.S., Carruthers, T.D., Waldner, C.L., \& Palmer, C.W. (2008). A comparison of diagnostic techniques for postpartum endometritis in dairy cattle. Theriogenology. 69(8), 714-723. https:/www.ncbi.nlm.nih. gov/pubmed/18242670.

Heidarpour, M., Mohri, M., Fallah-Rad, A.H., Dehghan Shahreza, F., \& Mohammadi, M. (2012). Hematological changes before and after treatment in dairy cows with clinical and subclinical endometritis. Comp Clin Pathol. 23, 97-101. doi: 10.1007/s00580-012-1576-5.

Hopper, R.M. (2015). Bovine Reproduction. 1st ed. USA: John Wiley \& Sons. doi: 10.1002/9781118833971.

Ivashkiv, R.M., Stefanyk, V.Y., Kudla, I.M., Tyranovets, V.I., Dmytriv, O.Y., \& Kostyshyn, Y.,Y. (2012). Zastosuvannya etiotropno-patohenetychnoyi terapiyi pry vymirakh koriv. Naukovyy visnyk LNUVMBT imeni S.Z. Gzhytskoho. 14(3), 71-73 (in Ukrainian).

Katsaraba, O.A., Dmytriv, O.YA., Kostyshyn, Y.Y., Ivashkiv, R.M., Kava, S.Y., \& Sachuk, R.M. (2017). Efektyvnist likuvannya pislyarodovoho endometritu koriv aerozolnym preparatom «Tsefhen». Naukovyy visnyk LNUVMB imeni S.Z. Gzhytskoho. 19(82), 230-234 (in Ukrainian). 
Kobylyukh, I.B., Stravskiy, Y.S., Stefanyk, V.Y., \& Kostyshyn, Y.Y. (2017). The influence of the preparation «Fos-Bevit» on the content of cholesterol and the concentration of urine acid in cows' organism and the processes in their organism after natal period. Scientific Messenger LNUVMBT named after S.Z. Gzhytskyj. 19(77), 204-207. doi:10.15421/nvlvet7744.

Savc, M., Duane, M., O'Grady, L.E., Somers, J.R., \& Beltman, M.E. (2016). Uterine disease and its effect on subsequent reproductive performance of dairy cattle: a comparison of two cow-side diagnostic methods. Theriogenology. 86(8), 1983-1988. https://www.ncbi.nlm.nih.gov/pubmed/27450885.

Sidashova, S.O., \& Gumenny, O.G. (2017). Rhythm of sexual cycles of cows and level of the hidden early embrionic mortality. Scientific Messenger LNUVMB, 19(78), 121-128. doi:10.15421/nvlvet7825.

Stefanyk, V.Y., Kostyshyn, Y.Y., Ivashkiv, R.M., Kudla, I.M., Tyranovets, V.I., \& Katsaraba, O.A. (2009). Eti- olohiya rozvytku metrytu u koriv ta metody likuvannya. Naukovyy visnyk LNUVMBT imeni S.Z. Gzhytskoho. 11(3), 152-157 (in Ukrainian).

Stravskyy, Y.S., Stefanyk, V.Y., Kostyshyn, Y., Katsaraba, O.A., Panich, O.P., \& Kalinina, O.Y (2015). Etiolohiya, patohenez, diahnostyka ta metody likuvannya koriv, khvorykh na metri Naukovo -tekhnichnyy byuleten Instytutu biolohiyi tvaryn ta Derzhavnoho naukovo-doslidnoho kontrolnoho instytutu veterynarnykh preparativ i kormovykh dobavok. 16(1), 257274 (in Ukrainian).

Williams, E.J., Fischer, D.P., Pfeiffer, D.U., England, G.C., Noakes, D.E., Dobson, H., \& Sheldon, I.M. (2005). Clinical evaluation of postpartum vaginal mucus reflects uterine bacterial infection and the inflammatory response to endometritis in cattle. Theriogenology. 63(1), 102-117. https:/www.ncbi.nlm. nih.gov/pubmed/15589277. 